\title{
Penerapan Metode Belajar Part and Whole untuk Meningkatkan Hasil Belajar Penjaskes Materi Senam Lantai (Lompat Kangkang)
}

\author{
I Ketut Jiwa \\ SMK Negeri 1 Mas Ubud \\ e-mail: KetutJiwa345@gmail.co.id
}

\begin{abstract}
Abstrak
Penelitian ini bertujuan untuk meningkatkan hasil belajar mata pelajaran Penjasorkes dengan materi Senam Lantai (Lompat Kangkang) pada siswa kelas X AK 1 Semester Satu SMK Negeri 1 Mas Ubud. Subjek penelitian ini adalah siswa kelas $X$ Pariwisata pada tahun ajaran 2016/2017 yang berjumlah 30 orang siswa. Penelitian ini merupakan penelitian tindakan kelas yang dilaksanakan dalam dua siklus. Setiap siklus terdiri dari 2 kali pertemuan yang di dalamnya terdiri atas perencanaan, pelaksanaan tindakan, observasi, evaluasi, serta refleksi. Data mengenai hasil belajar siswa dikumpulkan melalui lembar observasi aktivitas belajar siswa dan asesmen gerak senam lantai, Data yang telah dikumpulkan tersebut dianalisis dengan menggunakan analisis deskriptif. Hasil penelitian ini menunjukkan (1) penerapan metoda belajar Part and Whole dapat meningkatkan hasil belajar siswa. Adapun hasil yang dicapai dalam penelitian ini adalah: 1) hasil siklus I dengan nilai rata-rata 76,26 , dengan ketuntasan belajar mencapai $83,33 \%$, dan 2) hasil siklus II dengan nilai rata-rata 81,66 , dengan ketuntasan belajar mencapai $100 \%$. Dengan demikian maka pada siklus II tidak ada siswa yang belum tuntas dan penerapan metode belajar Part and Whole terbukti keberhasilannya.
\end{abstract}

Kata Kunci : Metode belajar Part and Whole, Hasil Belajar, Senam lantai Lompat Kangkang

\begin{abstract}
This study aims to improve the learning outcomes of Penjasorkes subjects with Floor Gymnastics (Kangkang Jump) material in class X AK 1 Semester 1 of SMK Negeri 1 Mas Ubud. The subject of this study was the $X$ grade students of Tourism in the 2016/2017 school year which amounted to 30 students. This research is a classroom action research conducted in two cycles. Each cycle consists of 2 meetings which consist of planning, action, observation, evaluation, and reflection. Data on student learning outcomes were collected through observation sheets of student learning activities and floor gymnastic motion assessments. The collected data were analyzed using descriptive analysis. The results of this study indicate (1) the application of Part and Whole learning methods can improve student learning outcomes. The results achieved in this study are: 1) the results of the first cycle with an average value of 76.26 , with learning completeness reaching $83.33 \%$, and 2) the results of the second cycle with an average value of 81.66 , with mastery learning reach $100 \%$. Thus, in the second cycle there were no students who had not finished and the implementation of Part and Whole learning methods proved successful.
\end{abstract}

Keywords: Method of learning Part and Whole, Learning Outcomes, Kangkang Jump Floor Gymnastics. 


\section{Pendahuluan}

Pendidikan merupakan kebutuhan yang harus dimiliki oleh setiap individu. Aspek yang harus diperhatikan dalam usaha peningkatan mutu pendidikan salah satunya melalui Proses Belajar Mengajar (PBM). Dengan demikian, peningkatan hasil belajar siswa akan dapat dicapai melalui proses belajar yang efektif. Upaya untuk melaksanakan pembangunan disektor pendidikan merupakan suatu kebutuhan yang wajib dilakukan untuk meningkatkan kualitas pendidikan nasional (Janaedi ,2015).

Pendidikan Jasmani Olahraga dan Kesehatan merupakan bagian dari pendidikan secara keseluruhan, bertujuan untuk mengembangkan aspek kebugaran jasmani, keterampilan gerak, keterampilan berfikir kritis, keterampilan sosial, penalaran, stabilitas emosional, tindakan moral, aspek pola hidup sehat dan pengenalan lingkungan bersih melalui aktifitas jasmani, olahraga dan kesehatan terpilih yang direncanakan secara sistematis dalam rangka mencapai tujuan pendidikan nasional. Pendidikan sebagai suatu proses pembinaan manusia yang berlangsung seumur hidup, pendidikan jasmani olahraga dan kesehatan yang di ajarkan disekolah memiliki peran yang sangat penting yaitu memberikan kesempatan kepada peserta didik untuk terlibat langsung dalam berbagai pengalaman belajar melalui aktifitas jasmani, olahraga dan kesehatan yang terpilih dan dilakukan secara sistematis. Oleh karena itu pembelajaran pendidikan jasmani olahraga dan kesehatan dalam pelaksanaannya memerlukan cara dan strategi yang tepat agar siswa dapat termotivasi untuk mengikuti pembelajaran dengan serius (Utama Bandi, 2011). Sehingga pendidikan jasmani harus diajarkan kepada setiap peserta didik pada semua jenjang pendidikan. Perencanaan pendidikan jasmani dilakukan secara seksama untuk memenuhi perkembangan, pertumbuhan, dan kebutuhan perilaku setiap anak. Maka pendidikan jasmani bukan hanya ditujukan untuk mengembangkan kemampuan psikomotorik, akan tetapi juga mengembangkan kemampuan kognitif dan afektif peserta didik (Tantra ,2018).

Menjadi guru pendidikan jasmani yang profesional tidak semudah yang dibayangkan banyak orang selama ini, salah persepsi menganggap guru pendidikan jasmani hanya bermodal peluit dan bola di sekolah. Bahkan sebaliknya, untuk menjadi guru pendidikan jasmani yang profesional lebih sulit dibandingkan dengan menjadi guru mata pelajaran yang lain. Mata pelajaran pendidikan jasmani lebih kompleks permasalahannya dibandingkan dengan pelajaran yang lain (Syahrin , 2017).

Rendahnya hasil belajar yang dicapai siswa untuk mata pelajaran Pendidikan Olahraga dan Kesehatan di SMK Negeri 1 Mas Ubud, karena belum optimalnya metode yang diterapkan guru untuk memupuk kemampuan pisik siswa dalam mengikuti kegiatan pembelajaran Penjasorkes terutama pada materi senam lantai. Berdasarkan hasil tes awal (Prasiklus) yang dilaksanakan pada tahap awal Penelitian ini hasil belajar siswa dengan nilai rata-rata 70,75 dengan ketuntasan belajar mencapai 44,44\%. Kondisi demikian mendorong peneliti untuk melakukan perbaikan-perbaikan melalui Penelitian Tindakan Kelas ini yang dilaksanakan di SMK Negeri 1 Mas Ubud.

Berdasarkan uraian diatas, maka judul yang diangkat dalam penelitian ini adalah : Penerapan Metode Belajar Part and Whole untuk meningkatkan Hasil Belajar Pendidikan Jasmani Olahraga dan Kesehatan Materi Senam Lantai (Lompat kangkang) Pada Siswa Kelas X AK 1 Semester I SMK Negeri 1 Mas Ubud Tahun Pelajaranb 2016/2017.

Metode pembelajaran part and whole digabungkan menjadi satu kesatuan dan tidak dapat dipisahkan, dalam pelaksanaan penelitian diharapkan metode ini dapat mempengaruhi peningkatan kemampuan gerak senam lantai pada siswa.

Metode pembelajaran part and whole mempunyai karakteristik: 1) Adanya Preview yaitu: tahap ini dilakukan sesuai dengan apa yang dilakukan dalam metode part and whole siswa diberikan informasi perihal yang dipelajari secara keseluruhan dari berbagai macam sumber, 2) Dilakukan percobaan: percobaan yang dilakukan dalam tahap ini juga sama dengan latihan yang dilakukan dalam praktek senam lantai, 3) Adanya Review yaitu: mulai dengan tahap ini cara memberikan review dilakukan penggabungan antara metode bagian dan metode keseluruhan. Guru memberikan umpan balik dan koreksi pertama dengan cara keseluruhan, kemudian ditekankan ke setiap individu bagian-bagian yang masih dirasa kurang. Sehingga setiap siswa mengalami feed back yang berbeda dan akan menjadi latihan penyempurnaan yang berbeda pula. Dimungkinkan siswa yang memiliki kelemahan yang sama akan dikelompokkan dalam kelompok yang sama, sehingga akan memudahkan mereka untuk belajar. Guru bertugas untuk berkeliling dan memberikan koreksi atas segala kesalahan baik secara perbagian ataupun keseluruhan, 4) Adanya Sintesis yaitu: setelah semua bagian yang 
diajarkan di atas dirasakan cukup kemudian dilakukan latihan secara keseluruhan. Latihan secara keseluruhan ini dilakukan ketika siswa yang telah memperoleh feed back dari guru untuk setiap kesalahan yang telah dilakukan. Latihan keseluruhan dilakukan sampai siswa mengerti bahwa tiap bagian yang telah dilatihkan merupakan penyumbang suksesnya gerak keseluruhan, dan 5) Dilakukan Pemantauan yaitu: pemantauan disini dimaksudkan adalah tahap pematangan. Latihan dapat kembali pada latihan bagian jika dirasa ada teknik bagian yang belum terkuasai dengan baik. Jika telah menguasai dengan baik teknik bagian latihan dapat pula diadakan secara keseluruhan. Tahap ini dapat dihentikan setiap saat ketika siswa mengulang kesalahan yang pernah dikoreksi. Dalam metode bagian dan keseluruhan ( part and whole) ini tidak ada batasan kapan akhir menggunakan bagian dan kapan menggunakan keseluruhan. $d$ whole.

Menurut Widijoto (2010:11) "Part-whole merupakan pendekatan motor learning yang mengajarkan aktivitas jasmani berdasarkan klasifikasi keterampilan dan informasi yang diterima. Part and whole (bagian-keseluruhan) akan sesuai untuk pembelajaran teknik dasar, yaitu dari bagian-bagian teknik hingga teknik secara keseluruhan (Winarno ,2013).

Winarno (1994) juga menyatakan bahwa metode part and whole ini merupakan metode pembelajaran yang dilakukan secara bertahap, dari pengenalan atau pembelajaran bagian hingga gabungan dari keseluruhan bagian. Oleh karena itu, penulis berpendapat bahwa metode part and whole dapat digunakan untuk pembelajaran anatomi manusia pada mahasiswa. (Citra ,2016).

\section{Metode}

Penelitian Tindakan Kelas ini dilakukan di SMK Negeri 1 Mas yang berlokasi di Jalan Ambarawati Mas - Ubud kabupaten Gianyar. Kegiatan Penelitian ini dilaksanakan di Kelas X.AK 1 Semester Satu SMK Negeri 1 Mas, yang berjumlah 36 orang karena hasil belajar siswa di kelas ini terhadap mata pelajaran Pendidikan Olahraga dan Kesehatan dari hasil test awal (pra siklus) nilai rata-rata mencapai, mencapai 70,75 dan ketuntasan belajar mencapai $44,44 \%$. sehingga perlu ditangani untuk dilakukan perbaikan-perbaikan.

Rancangan penelitian tindakan kelas dipusatkan pada situasi dalam proses sosial belajar di kelas juga melibatkan siswa dan guru, sehingga penelitian tindakan kelas berlangsung secara kolaborasi. Dalam pelaksanaan proses pemblajaran di kelas, bahwa rancangan penelitian ini dilakukan atas dasar empiris yang mendukung program penelitian tindakan kelas.

Untuk mendapat gambaran yang lebih jelas tentang rancangan penelitian dapat dilihat bagan di bawah ini sebagai berikut.

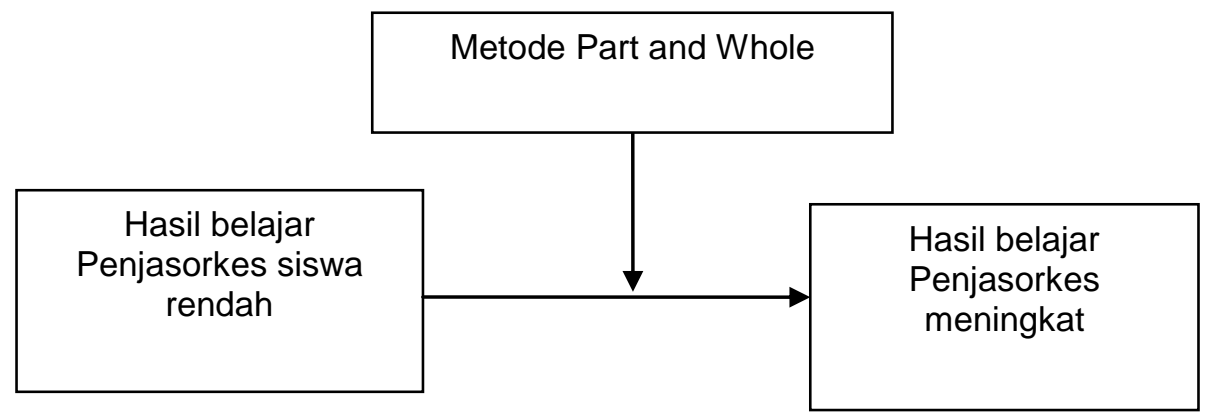

Gambar 1. Rancangan Penelitian

Pelaksanaan penelitian ini dibagi menjadi beberapa siklus. Masing-masing siklus dipaparkan sebagai berikut.

1. Perencanaan

Pada tahapan ini peneliti/guru membuat rancangan tentang fokus permasalahan yang perlu mendapatkan perhatian yaitu :

a. Menyusun kelengkapan administrasi guru termasuk RPP dan lainnya

b. Menyiapkan Instrumen penelitian untuk guru dan siswa

c. Menyiapkan format evaluasi pretest dan postest

d. Menyiapkan sumber belajar yang berupa materi diskusi, tentang senam lantai ( lompat Kangkang) 
e. Menyiapkan siswa untuk mengikuti pembelajaran Penjasorkes dengan metoda Part and Whole.

f. Mengembangkan scenario pembelajaran dan menyesuaikan dengan metode yang dilaksanakan

2. Pelaksanaan

a. Guru melaksanakan apersepsi, motivasi untuk mengarahkan siswa memasuki KD yang akan dibahas

b. Guru menjelaskan tujuan pembelajaran yang akan dicapai

c. Guru menjelaskan materi pembelajaran hari itu dengan menjelaskan langkah kerja metode part and whole

d. Guru mendiskusikan kembali dengan seluruh siswa, bila perlu mengadakan pengembangkan skenario pembelajarani dan menjelaskan tentang penerapan metode part and whole dalam pembelajaran Pendidikan Jasmani Olahraga dan Kesehatan, yaitu siswa akan diberikan latihan gerak sesuai metode part and whole dalam melakukan gerakan sebam lantai. Bila ternyata siswa ada yang belum mencapai gerakan secara sempurna yang diberikan tuntunan oleh guru.

e. Guru mengadakan tes atau ulangan

3. Pengamatan

a. Observasi (kolaborasi) mengamati kegiatan guru pada saat pembelajaran dan mengamati kegiatan siswa dengan menggunakan instrument pengamatan pembelajaran guru dan siswa

b. Guru mengevaluasi respon siswa selama pembelajaran dari angket yang diisi oleh siswa

c. Guru mengevaluasi kegiatannya dengan menggunakan angket guru

4. Refleksi

Hasil evaluasi direfleksikan untuk tindakan selanjutnya dengan pembahasan pada hasil observasi. Kekurangan yang terjadi pada siklus I dikaji lebih lanjut dan diperbaiki, kemudian dilakukan tindakan pada siklus II. Sedangkan pada Siklus II akan dilaksanakan langkah-langkah yang sama seperti yang dilakukan pada siklus I, namun pelaksanaannya lebih dimantapkan pada kmponen-komponen yang belum mencapai hasil maksimal. Sehingga melalui perbaikan tersebut hasilnya akan lebih sempurna. Masukan-masukan dari siswa dan guru sangat diharapkan melalui refleksi ini guna penyempurnaannya.

Pengumpulan data dilakukan dengan menggunakan Instrumen Penelitian dan pelaksanaanya adalah sebagai berikut.

1. Test Uji Kompetensi siswa dilaksanakan dengan menggunakan instrumen test pre test, dan post test, soal menyangkut kemampuan akademik dan test soal praktek. Dalam test uji kompetensi ini dilakukan penilaian secara holistik yakni menguji pengetahuan, sikap dan ketrampilan siswa untuk mata pelajaran Penjasorkes di Kelas X.AK 1 SMK Negeri 1 MasUbud Semester satu tahun pelajaran 2016/2017.

2. Lembar observasi, (Observasi) yang digunakan pada saat pelaksanaan pelajaran atau pada saat pelajaran berlangsung. Yang diobservasi adalah kemampuan siswa baik dalam bentuk test akademik maupun test praktek. Dalam observasi ini Peneliti berkolaborasi dengan teman sejawat (guru mata pelajaran lain), sebagai kolaborator. Hasil observasi yang dilakukan bersama dengan kolaborator dijadikan bahan kajian pada saat melakukan analisis data tentang hasil yang telah dicapai oleh siswa.

Indikator keberhasilan yang digunakan dalam penelitian ini adalah apabila jumlah siswa sebanyak $80 \%$ telah mencapai nilai sama dengan atau lebih dari KKM yang telah ditetapkan sekolah yaitu (75) maka Penelitiannya telah dikatakan berhasil.

\section{Hasil Dan Pembahasan}

Pada Siklus I ini dilaksanakan selama 2 kali pertemuan. Selama proses tindakan berlangsung peneliti selalu mengamati dan merekam setiap kegiatan yang terjadi melalui catatan lapangan (field note), agar hasil pengamatan yang telah dilaksanakan tercatat perkembangannya.

Pada siklus I pembelajaran Penjasorkes dengan materi senam lantai (lompat Kangkang), melalui penerapan metode Part and Whole dapat berhasil dengan baik. Hal ini dapat dilihat pada perkembangan kegiatan siswa dari pertemuan pertama sampai kedua ada kemajuan yang baik dari prasiklus. Perkembangan tersebut membawa dampak terhadap siswa yang kelihatannya lebih semangat dan menyenangi pembelajaran Penjasorkes. 
Walaupun telah terjadi peningkatan hasil belajar yang dicapai siswa namun masih ada kelemahan yang terdapat pada siswa antara lain beberapa orang siswa belum mampu sepenuhnya melakukan gerakan senam lantai (Lompat Kangkang) dan masih ada 6 orang siswa yang dapat menuntaskan pembelajarannya di siklus I. Dengan dilaksanakannya metoda part and whole, diharapka pada siklus II semua siswa dapat dicapainya ketuntasan belajar Penjasorkes ke tingkat yang lebih baik. Kelemahan-kelemahan yang terjadi di siklus I dapat diperbaiki pada siklus II.

Pada siklus berikutnya (siklus II) dilakukan refleksi bagi siswa yang belum mencapai target pemenuhan KKM atau ketuntasan belajar.Sedangkan bagi siswa yang telah mencapai ketuntasan belajar pada siklus I masih diberi kesempatan untuk memperbaiki hasil belajarnya ke tingkat yang lebih baik lagi.

Pada pertemuan siklus kedua materi pokok pembelajaran sama dengan pertemuan pada siklus pertama. Aturan dan pelaksanaanya sama seperti pada pertemuan pertama. Masingmasing kelompok siswa hanya melakukan satu kali saja pada setiap sesi. Pada pertemuan kedua ini dilaksanakan evaluasi proses belajar tentang ketrampilan gerak lompat kangkang pada senam lantai secara tepat pada siklus II. Peneliti menekankan pada cara siswa melakukan aktivitas gerak senam lantai tentang lompat kangkang, sehingga kelemahan - kelemahan pada siklus sebelumnya dapat di perbaiki pada siklus II ini. Pada akhir siklus kedua peneliti melakukan refleksi atas tindakan yang telah dilakukan selama siklus kedua dilaksanakan. Proses pembelajaran yang telah dilakukan pada siklus kedua ini sudah meningkat bila dibandingkan dengan proses pembelajaran pada siklus satu .Pada siklus dua kualitas pembelajaran ketrampilan siswa terhadap gerakan senam lantai tentang lompat kangkang secara tepat dengan menggunakan metode part and whole dengan baik. Hasil yang dicapai mengalami peningkatan dengan jumlah rata-rata 81,66 , dan ketuntasan belajar siswa mencapai $100 \%$. Melihat kenyataan hasil refleksi dan tindakan tersebut di atas, secara klasikal ketuntasan belajar telah melampui batas KKM yang ditetapkan disekolah yaitu 75 . Dengan demikian perbandingan hasil penlitian tindakan yang dilakukan dari pra siklus, sampai dengan siklus kedua hasilnya dapat dilihat pada Grafik dibawah ini.

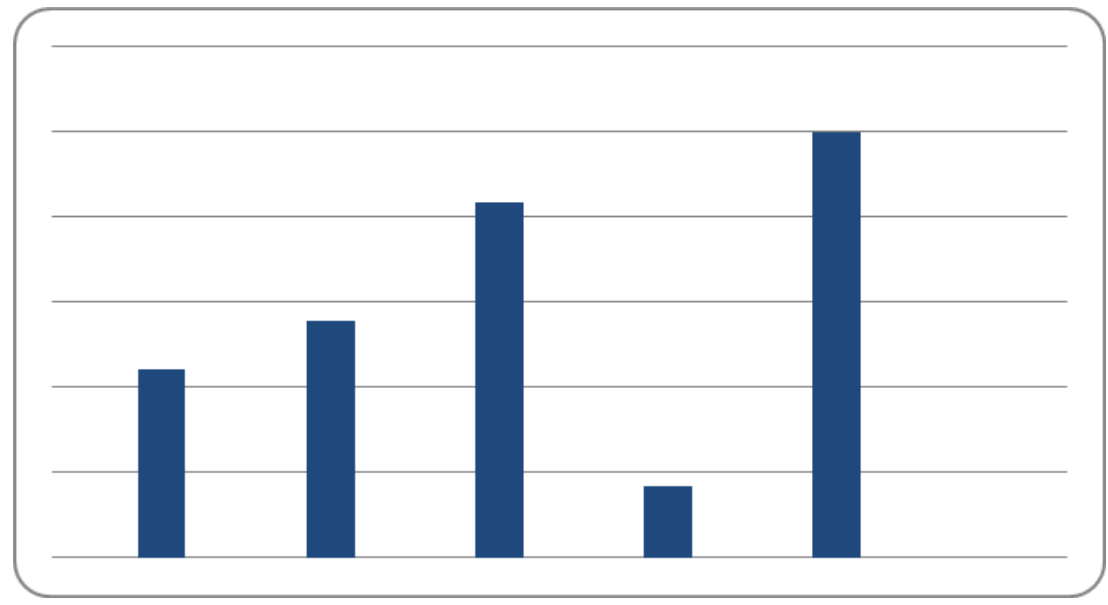

Gambar 2. Grafik Penelitian Prasiklus, Siklus I dan Siklus II

1. Ketuntasan belajar yang dicapai pada Prasiklus $=44,44 \%$

2. Siswa yang belum tuntas pada Prasiklus $=55,56 \%$

3. Ketuntasan belajar yang dicapai pada siklus I $=83,33 \%$

4. Siswa yang belum tuntas pada siklus I $=16,67 \%$

5. Ketuntasan belajar yang dicapai pada Siklus II $=100 \%$

6. Siswa yang belum tuntas pada siklus II $\quad=0 \%$

Dengan demikian pada siklus II tidak ada lagi siswa yang hasil belajar mata pelajar Pendidikan Jasmani Olahraga dan Kesehatan dibawah KKM. Hal ini terbukti bahwa dengan penerapan metode Part and Whole siswa mampu meningkatkan hasil belajarnya dengan baik.

Dari tampilan hasil pada gambar grafik prasiklus, siklus I, siklus II, nampak adanya peningkatan yang signifikan yang telah dicapai oleh siswa. Untuk itu penerapan metode Part 
and Whole baik dilaksanakan bagi siswa untuk meningkatkan hasil belajar Pendidikan Jasmani Olahraga dan Kesehatan.

Hasil penelitian ini sejalan dengan hasil penelitian yang dilakukan oleh Winanda, dkk (2015) yang berjudul Peningkatkan Hasil Belajar Lari Sprint 60 Meteri Dengan Metode Part Whole Part Siswa Kelas VIII. Hasil penelitiannya menyatakan bahwa: dari hasil tes lari sprint 60 meter, diketahui rata-rata nilai Implementasi sebesar 57,1 sedangkan nilai rata-rata pada siklus I sebesar 76 dan pada siklus ke II yaitu sebesar 88,6 Hal ini menunjukkan bahwa pembelajaran dengan menggunakan metode part whole part (bagian perbagian) dapat meningkatkan hasil belajar lari sprint 60 meter pada siswa kelas VIIIA SMP Negeri 01 Jawai Kabupaten Sambas.

Selanjutnya penelitian yang dilakukan oleh Dewi (2016) yang berjudul Pengaruh Metode Part And Whole Terhadap Prestasi Belajar Anatomi Manusia Pada Mahasiswa Fakultas Pendidikan Olahraga dan Kesehatan IKIP PGRI Bali. Hasil penelitian didapatkan pengaruh yang signifikan dari metode part and whole terhadap prestasi belajar anatomi manusia dengan nilai $t$ hitung 12,387 dan $p=0,000$ pada taraf signifikasnsi $5 \%$. Dengan demikian dapat disimpulkan bahwa metode part and whole berpengaruh terhadap prestasi belajar anatomi manusia pada Fakultas Pendidikan Olahraga dan Kesehatan IKIP PGRI Bali.

\section{Kesimpulan}

Berdasarkan hasil penelitian tindakan kelas dan pembahasan, maka dapat ditarik suatu kesimpulan sebagai berikut.

1. Penerpan metode belajar Part and Whole dalam pembelajaran Pendidikan Jasmani Olahraga dan Kesehatan dapat meningkatkan hasil belajar siswa dengan baik

2. Peningkatan tersebut nampak dari: a) Hasil Prasiklus mencapai nilai rata-rata 70,75, dengan ketuntasan belajar mencapai $44,44 \%$, b) Hasil siklus I dengan capaian nilai ratarata 76,26 dengan ketuntasan belajar mencapai $83,33 \%$, dan c) Hasil siklus II dengan capaian nilai rata-rata 81,66 dengan ketuntasan belajar mencapai $100 \%$.

Dengan demikian dapat dikatakan bahwa penggunaan metode Part and Whole dalam pembelajaran Pendidikan Jasmani Olahraga dan Kesehatan dapat meningkatkan hasil belajar siswa dalam melakukan gerakan senam lantai tentang lompat kangkang secara signifikan.

Setelah disimpulkan dari hasil penelitian ini, maka perlu kiranya dibuat saran-saran untuk menjadi perhatian dalam menetapkan kebijaksanaan yang berhubungan dengan mutu pembelajaran, khususnya mata pelajaran Penjaskes. Saran-saran tersebut adalah sebagai berikut:

1. Kepada guru Pendidikan Jasmani Olahraga dan Kesehatan, hendaknya dapat menentukan metode belajar yang tepat untuk memotivasi semangat siswa dalam mengikuti Pelajaran Penjasorkes di SMK Negeri 1 Mas ubud.

2. Kepada sekolah sebagai lembaga yang membina generasi muda, bahwa, melalui pembelajaran Penjasorkes dapat meningkatkan pengetahuan dan ketrampilan siswa yang berkaitan dengan aktivitas jasmani, perkembangan estetikan dan perkembangan sosial

3. Sekolah menekankan agar siswa selalu semangat dalam mengikuti Pendidikan Jasmani Olahraga dan Kesehatan untuk nmengembangkan kepercayaan diri dan kemampuan untuk menguasai keterampilan gerak dasar yang akan mendorong partisipasinya dalamn aneka aktivitas jasmani.

4. Kepada peneliti lain sebagai kelanjutan dan rekonstruksi dari penelitian ini, agar lebih baik dari apa yang telah dilaksanakan oleh penulis.

\section{Daftar Pustaka}

Arikunto, Suharsimi. 2002. Prosedur Penelitian Suatu Pendekatan Prakti. Jakarta PT. Rineksa Cipta.

Dewi, Putu Citra Permana. Pengaruh Metode Part And Whole Terhadap Prestasi Belajar Anatomi Manusia Pada Mahasiswa Fakultas Pendidikan Olahraga Dan Kesehatan IKIP PGRI Bali. Jurnal Pendidikan Kesehatan Rekreasi, [S.I.], v. 2, n. 2, p. 81-85, aug. 2016. ISSN 2337-9561.

Citra ,Putu (2016). Pengaruh Metode Part And Whole Terhadap Prestasi Belajar Anatomi Manusia Pada Mahasiswa Fakultas Pendidikan Olahraga Dan Kesehatan Ikip Pgri Bali . Jurnal Pendidikan Kesehatan Rekreasi Volume 2, No.1: 81 - 85, Agustus 2016 
Engkos S.R. 1994. Penjaskes. Jakarta; Erlangga.

Janaedi ,Anas (2015). Survei Tingkat Kemajuan Pendidikan Jasmani, Olahraga, Dan Kesehatan Di Sma, Smk, Dan Ma Negeri Se-Kabupaten Gresik . Jurnal Pendidikan Olahraga dan Kesehatan Volume 03 Nomor 03 Tahun 2015, 834 - 842

Slamet, S.R. 1994. Penjaskes 3. Jakarta; Tiga Serangkai.

Syarifuddin, Aib. 1997. Penjaskes 1,2,3. Jakarta; PT. Gramedia Widiasmara Indonesia.

Syahrin ,Alfi (2017). Peran Guru Pendidikan Jasmani Dalam Membentuk Karakter Siswa Pada Mts Se-Banda Aceh Tahun Pelajaran 2016/2017 . Jurnal IImiah Mahasiswa Pendidikan Jasmani, Kesehatan dan Rekreasi Fakultas Keguruan dan IImu Pendidikan Unsyiah Volume 3. Nomor 2 : 76 - 91 Mei 2017.

Winanda, dkk. 2015. Peningkatkan Hasil Belajar Lari Sprint 60 Meter Dengan Metode Part Whole Part Siswa Kelas VIII. Jurnal Pendidikan dan Pembelajaran Volume 4 Nomor 9 UNTAN.

Winarno ,M.E (2013). Penerapan Metode Part-Whole Untuk Meningkatkan Keterampilan Senam Ketangkasan Gerakan Round-Off Pada Siswa Kelas Xi Rpl-3 Smk Negeri 5 Malang . Jurnal Universitas Negeri Malang.

Tantra ,Sandey (2018). Revitalisasi Pendidikan Jasmani untuk Anak Usia Dini melalui Penerapan Model Bermain Edukatif Berbasis Alam . Jurnal Pendidikan Jasmani dan Olahraga JPJO 3 (1) (2018) 41-51 